\title{
REDUCTION IN WATER LEVELS AND REGIONAL WARMING OF THE AMAZON RIVER FROM PERU TO THE ATLANTIC OCEAN IN BRAZIL DUE TO THE EFFECTS OF THE 2016 ENSO
}

\author{
Newton Silva de Lima ${ }^{1}$, Aldemir Malveira de Oliveira², Eriberto Barroso Façanha Filho', \\ José Olavo Nogueira Braga ${ }^{1}$, Ricardo Silva Figueiredo ${ }^{1}$, Robson Matos Calazães ${ }^{1}$, William Dennis Quispe ${ }^{1}$, \\ Roseilson Souza do Vale ${ }^{3}$ and Alan dos Santos Ferreira ${ }^{1}$
}

ABSTRACT. In situ observations of the tendencies of the ENSO (El Niño Southern Oscillation) phenomenon combined with a trend of regional warming in both western and eastern Amazônia were registered by the Amazon River Peru-Brazil Expedition on the Amazon River. Temperatures were taken at four positions on the river (edge, middle of the canal, $1 \mathrm{~m}$ deep below the surface, and ambient air), air pressure and humidity, and the velocity and direction of the wind were the parameters that were sampled from the Peruvian city of Iquitos beginning in July 2016, to the Brazilian city of Macapá at the mouth of the Amazon River ending in December 2016. The results suggest that there was a decline in water levels along the river during the entire observation period due to the El Niño event that occurred in 2014,15 and 16 .

Keywords: Amazônia, El Niño, Iquitos, hydroclimate.

RESUMO. Observações in situ das tendências do fenômeno ENOS (El Niño Oscilação Sul) combinadas com uma tendência de aquecimento regional na Amazônia ocidental e oriental foram registradas pela Expedição Rio Amazonas Peru-Brasil no Rio Amazonas. As temperaturas foram registradas em quatro posições no rio (borda, meio do canal, $1 \mathrm{~m}$ abaixo da superfície e ar ambiente), pressão do ar e umidade, e a velocidade e direção do vento foram os parâmetros amostrados desde a cidade peruana de Iquitos em julho de 2016, a cidade brasileira de Macapá na foz do Rio Amazonas em dezembro de 2016. Os resultados sugerem que houve um declínio nos níveis de água ao longo do rio durante todo o período de observação devido ao evento El Niño que ocorreu em 2014, 2015 e 2016.

Palavras-chave: Amazônia, El Niño, Iquitos, hidroclima.

\footnotetext{
${ }^{1}$ Universidade Luterana do Brasil - Campus Manaus, Manaus, AM, Brazil - E-mails: newtonulbra@gmail.com, eribertofacanha@seduc.net, olavonbraga@yahoo.com.br, rics.fig@gmail.com, matoscalazaes@gmail.com, william.exner@bol.com.br, alans_ferreira@hotmail.com

2Universidade Federal do Amazonas, Matemática, Manaus, AM, Brazil - E-mail: amoliveira@gmail.com

${ }^{3}$ Universidade Federal do Oeste do Pará, Geociências, Santarém, PA, Brazil - E-mail: roseilsondovale@gmail.com
} 


\section{INTRODUCTION}

Changes in atmospheric circulation in the tropical zone (Walker cell) induce change in rainfall patterns, devastating floods, and severe droughts that can drastically affect the lives of millions of people (Mohtadi et al., 2017). In the mosaic of landscapes that is tropical South America the tendencies for rainfall, in the Amazon in eastern Brazil, to the northwest of Peru are well-defined by long-term hydrological data for the Amazon basin that were recorded during the $20^{\text {th }}$ century.

During this period the tendency for rainfall during the three most humid months and for the subsequent superficial runoff rate during the three months with the greatest runoff for the northeastern region of Brazil demonstrated a slow increase over long periods (Marengo et al., 1998). In 2016 the Amazon River Expedition from Peru to Brazil observed tendencies in which a prolonged ENSO event combined with a trend of regional warming increased the demand for water from the reservoirs of Brazilian hydroelectric plants in the Northeast, Central-West, and Southeastern regions of Brazil (CCEE, 2017), and caused strong rains in the Southern region of Brazil (CPTEC, 2016).

According to Jiménez-Muñoz et al. (2016), this event was associated with warming that was without precedent and an extreme drought in the Amazon, compared to other strong ENSO events in 1982/83 and 1997/98. The typical conditions of drought caused by the ENSO were observed and described by Jiménez-Muñoz et al. (2016), as occurring only in the eastern Amazon, while in the western region of the Amazon there prevailed an uncommon level of humidity. For researchers this situation can be attributed to the humid-dry dipole at the location of maximum warming of the surface of the equatorial central Pacific Ocean. This humid-dry dipole was also confirmed in the current study through a time series of temperature readings at 4 distinct points (edge, middle of the canal, $1 \mathrm{~m}$ deep below the surface, and ambient air) along the Amazon River from the west in Iquitos, Peru, to the east in Macapá, Brazil by the research team of the Amazon River Expedition from Peru to Brazil in 2016. According to Erfanian et al. (2017), the empirical relationships between rainfall and sea surface temperatures (SST) in the Pacific and Atlantic Oceans represent the factors of tropical ocean variability responsible for the observed precipitation anomalies. These results indicate that the warmer than normal SST for the tropical Pacific and Atlantic Oceans (including El Niño events) were the principal causes of extreme droughts in South America, however, researchers are still unable to explain the severity of the precipitation deficits observed in 2016 in a substantial portion of the Amazon region. Therefore, hydroclimatic variability in South America is strongly coupled, on a large scale, to oceanic and atmospheric phenomena. Specifically, the El Niño Southern Oscillation (ENSO) that affects climatological and hydrological conditions has a "terrestrial - atmospheric" mechanism that forms a bridge between these two domains and connects the anomalies of SST of the Pacific and Atlantic Oceans (Poveda \& Mesa, 1997).

The variability of winds that favored the formation of the $\mathrm{El}$ Niño Southern Oscillation (ENSO) between 2014 and 2016 and their possible contribution to drought and hydrological stress of the Amazon River were mentioned in the commentaries of Zhu et al. (2016) on reliable predictions of ENSO. These inferred predictions are strongly dependent on correct modeling of the meridional Sea Surface Temperature (SST) gradient as well as its delicate feedback with the zonal ENSO mode. In Ineson et al. (2018) the western equatorial Pacific Ocean surface temperature anomalies don't seem to impede the development of the $\mathrm{El}$ Niño, although the strong activity of the western wind in 2015, compared to 2014, is a fundamental difference between the two years, and this was also noted by Hu \& Fedorov (2018). When the causes of these changes are analyzed over the last two decades the average SST anomalies are weakened towards the west, in direction of the central Pacific, and this represents an indicator that needs more observation.

\section{MATERIAL AND METHODS}

An automatic meteorological station was installed on roof of the five passenger transport ships (Fig. 1) used in this research expedition (Fig. 2). The station was free from obstacles that would impede accurate measurement of the variables of interest (temperature, humidity, pressure, wind speed and direction, dew point, and rainfall).

\section{Sampling and chronogram}

For monitoring of weather and climate during the period of the research were used: I - FLIR-E60 thermal imager (Table 3) and II - Mira digital thermometer - LASER, Minipa MT-360 sensors. Measurement of ambient air temperature, and the temperature at the edge of the river, middle of the canal, and at $1.0 \mathrm{~m}$ below the river's surface a meteorological station with uninterrupted recording (15 days + 15 days) with data collection (ambient air temperature, humidity, pressure, wind speed and direction, dew point) were measured every 5 minutes, and in situ two liter water samples were taken at each sampling point along the entire 

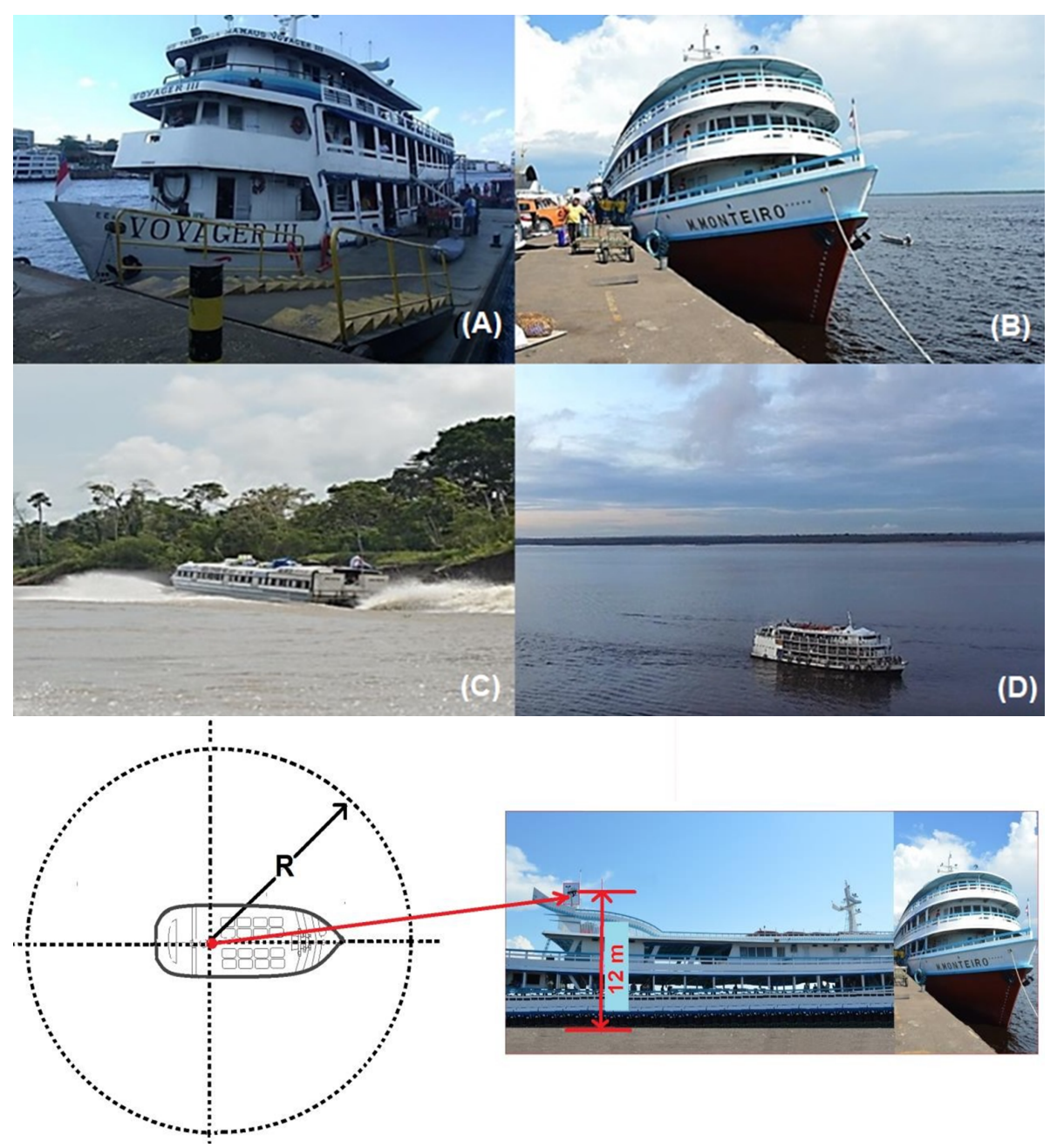

Figure 1 - Ships used in the Amazon River Expedition (2016-18).

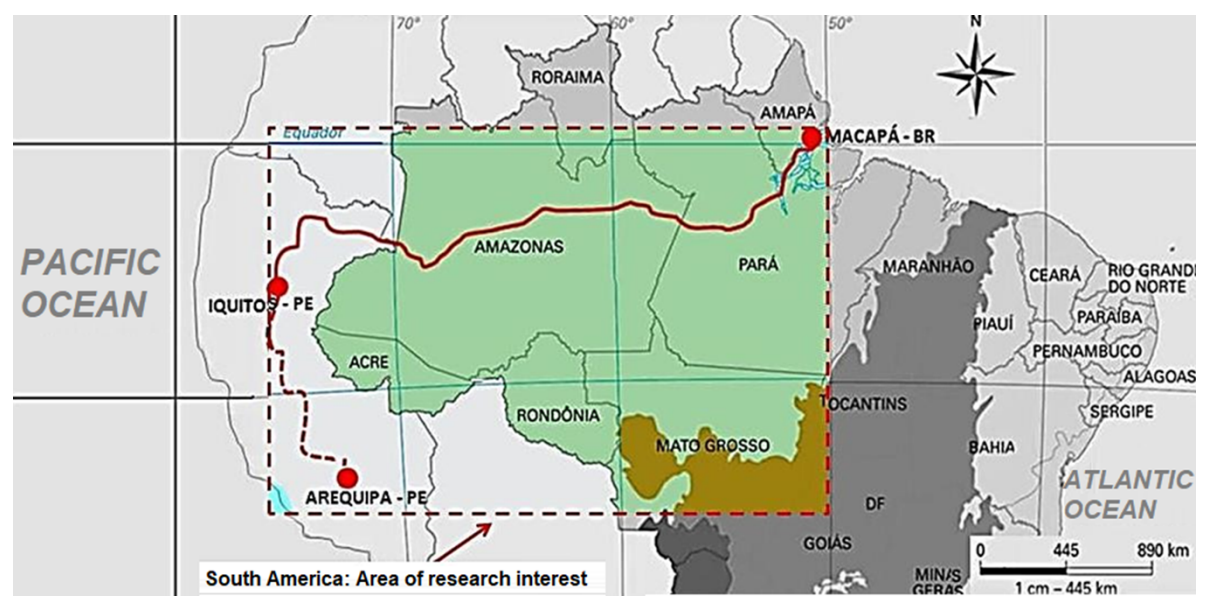

Figure 2 - Map of the Expedition (Arequipa-Peru; Iquitos-Peru; Macapá-Brazil). 
river. Temperature values are a composite of 10 in situ readings taken at each sampling point. The geographic coordinates of the sampling points were taken along with a description of the weather (climate) and the time at the moment of collection, and samples were labeled accordingly (Steps 1 and 2 of the Amazon River Expedition protocol).

\section{Laboratory analysis of water samples (and methods)}

1. Alkalinity (APHA, 2003; Palissa, 1972);

2. Calcium $\left(\mathrm{Ca}_{2}{ }^{+}\right)$, hardness, and Magnesium $\left(\mathrm{Mg}_{2}{ }^{+}\right)$(APHA, 1985; Golterman et al., 1978);

3. Chlorides (FENANTHROLINE - FIA), (Mackereth et al., 1978; Golterman, 1971);

4. DQO with potassium dichromate (APHA, 2003; Mackereth et al., 1978);

5. Total and Dissolved iron (FIA) (APHA, 2003);

6. Phosphate $\left(\mathrm{PO}_{4}\right)(\mathrm{APHA}, 2003$; Palissa, 1972);

7. Total phosphorus and nitrogen ( $\mathrm{N}$ and P-TOTAL) (Valderrama, 1981);

8. Total phosphorus (FIASTAR) (APHA, 2003; IS0 5861, $\mathrm{s} / \mathrm{d})$;

9. Nitrate (FIA) (Golterman et al., 1971);

10. Ammoniacal nitrogen $\left(\mathrm{NH}_{3}\right)$ (FIA - Flow Injection Analysis) Nessler reagent method;

11. Silicates (Silica - Molybdenum blue method) (Golterman et al., 1978; Mackereth et al., 1978);

12. pH (hydrogen ion concentration) (APHA, 2003);

13. Potassium and sodium by flame emission spectroscopy (Mackereth et al. 1978);

14. Total suspended solids (STS) (APHA, 2003);

15. Sulfate (APHA, 2003);

16. Temperature (FLIR-E60 thermal imager);

17. Turbidity (turbidity meter);

18. Color (spectrophotometer).

Done only between Manaus (Brazil) and Macapá (Brazil).

\section{Statistical modeling and georeferencing of data}

The time series of temperature reading along the Amazon River were processed and analyzed using the Marine Modeling and Analysis Branch Oper H.R. (Verification ensemble) of NOAA/NWS/NCEP/EMC (ftp://ftpprd.ncep.noaa.gov/pub/data/ $\mathrm{nccf} / \mathrm{com} / \mathrm{gfs} / \mathrm{prod}$ ). For the characterization of the composition of the El Niño event during this period the temperature gradients of the SST of the equatorial Atlantic and the eastern equatorial Pacific were constructed. All sampling points were georeferenced using a GPS (GARMIN - E60 and the software TrackMaker ${ }^{\circledR}$ ), and the creation of a thematic map for sampling points was done using ArcGIS ${ }^{\circledR}$. Flux measurements (temperature, humidity, pressure, wind speed and direction) were taken using a meteorological station (Vantage Vue/DAVIS Instruments Corporation, WeatherLink 6.0.3), using the static method (Lima et al., 2017), for covariances (Eddy Covariance).

\section{RESULTS AND DISCUSSION}

The decrease in the water level of the Amazon River between 2014 - 2016 was observed through the use of meteorological and hydrological stations of National Water Agency of Brazil (ANA - Agência Nacional de Águas) in 2013, 2014, 2015 and 2016, with hydrological data coming from the Hydrometeorological Network which is operated by the Geological Service of Brazil, and also from the COLA - Center for Ocean-Land-Atmosphere Studies/Virginia-USA (http://wxmaps.org/pix/clim). Figure 3 shows these data in the form of periods of flooding and low water (Tables 2 and 3) in the periods of high water on the upper Solimões (Amazon River) at Tabatinga-AM/Brazil (No. 10100000), the frontier between Brazil-Colombia-Peru, at the Itapeuá station (No. 131500000), at the middle Solimões at Tapauá-AM/Brazil, and also at Manacapuru-AM/Brazil (No. 14100000), above the city of Manaus/Brazil. This control has a strong degree of significance and ends at Óbidos-PA/Brazil, with the cities of Itacoatiara-AM/Brazil and Parintins-AM/Brazil between Manaus and Óbidos. The station at Careiro-AM/Brazil (No. 15040000) below Manaus demonstrates the reduction in the Rio Negro which bathes the city.

Figure 3 shows prediction of COLA (Center for Ocean-Land-Atmosphere Studies) for hydrological monitoring during 2014-2015-2016 by ANA (National Water Agency). For the month of January 2014, the forecast for rainfall over the Amazon indicated areas of concentration of rainfall with significant accumulation in the States of Rondônia, the west of 
Table 1 - Additionally, in situ analyses of $\mathrm{pH}, \mathrm{O}_{2}$, conductivity, and $\mathrm{O}_{2}$ saturation were conducted on all water samples.

\begin{tabular}{|l|c|c|c|c|}
\hline MATERIAL & SPECIFICATION & TEMP. $\left({ }^{\circ} \mathbf{C}\right)$ & ELECTROMAGNETIC SPECTRUM & EMISSIVITY \\
\hline WATER & LAYER THICKNESS $>0.1 \mathrm{~mm}$ & $0-100$ & ALL & $0.95-0.98$ \\
\hline
\end{tabular}

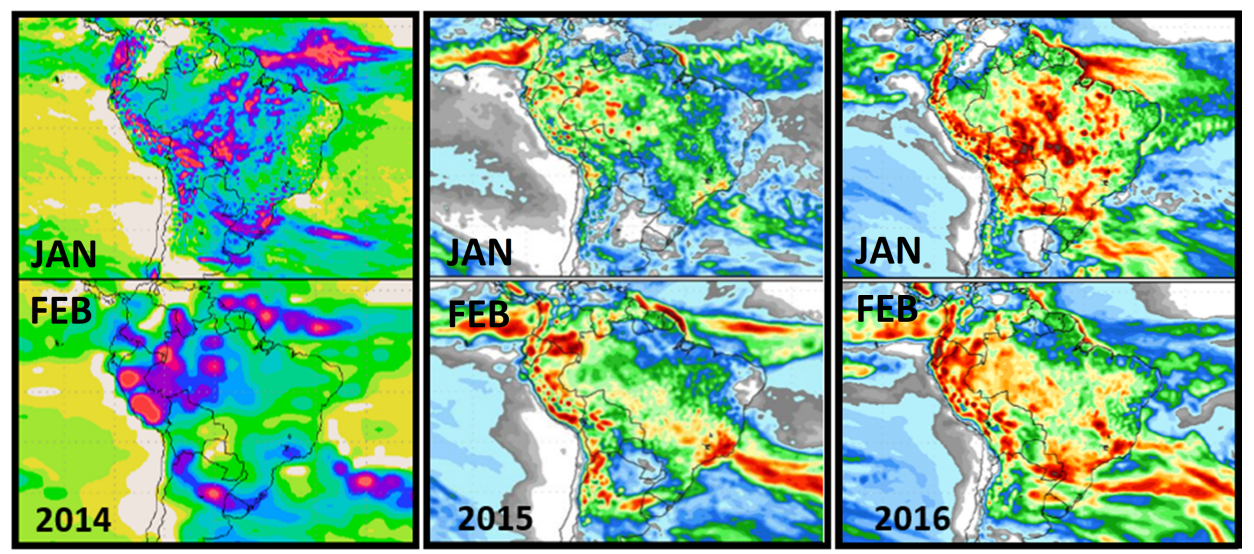

Figure 3 - Panel of maps of the Amazon showing climatological prognostics for rainfall prediction during January through February for 2014-2015-2016. (Source: http://wxmaps.org/pix/clim - COLA/Virginia-USA).

Mato Grosso, the southeast of Amazonas and generalized rainfall over Pará. During January and February 2014 the forecast for rainfall indicated more significant accumulation over Amazonas, Acre and Rondônia. In January 2015 a frontal system occurred over the southeast of Brazil. The highest rainfall accumulation was in the Upper Solimões basin and along its principal tributaries such as the Japurá, Juruá and Purus Rivers, the West and southwest of Amazonas, the State of Acre, the north of Rondônia, and the west of Mato Grosso. In Solimões, during January and February 2015, the forecast indicated the possibility of maintenance of the rainfall pattern of the previous week with significant accumulations of rainfall concentrated in Bolivia, Peru and Colombia, and also over the basin in Brazil in the western regions of Amazonas, Acre and Rondônia. Finally, in January 2016 there were significant volumes of rainfall over a large part of the legal Amazon. These accumulations were associated with the influence of the Intertropical Convergence Zone (ITCZ) and also with the passage of frontal systems that contributed to the formation of areas of instability which organized or fortified the Humidity Convergence Zone ( $\mathrm{HCZ})$ or the South Atlantic Convergence Zone (SACZ). The forecast for rainfall for February 2016 indicated more significant accumulation concentrated in an area running from the northwest to the southeast over the
Colombia and Peru, passing through the central-west of Brazil in the direction of the Atlantic Ocean.

Figure 4 shows systems that were responsible for the atmosphere dynamics on July 26, 2016 between 05:00 LT and 17:00 LT, the first day of the Amazon River Expedition when it left Iquitos, Peru, for Manaus, Brazil. The Intertropical Convergence Zone (ITCZ) is in the north of South America and reaches the Amazon region, and there is a cold front that is developing in the southern Atlantic Ocean and is penetrating the southern region of Brazil.

The reduction in hydrological and water quality characteristics of the Amazon River between 2014 and 2016 (Tables 2 and 3, ANA) were registered (Tables 3 and 4) by the Amazon River Expedition during the ENSO, and these climatological observations showed little movement of the Intertropical Convergence Zone (ITCZ) towards the southern hemisphere (Figs. 4 and 5). This is a consequence supposedly caused by the weakening of the winds, and this question remains open for many researchers, including Ashok et al. (2007), Kao \& Yu (2009), Kug et al. (2009), McPhaden et al. (2011), and Hu \& Fedorov (2018), all of whom affirm that the changes in these winds, which are considered to be natural forcings for the El Niño, is still cause for debate, and that the occurrence of 


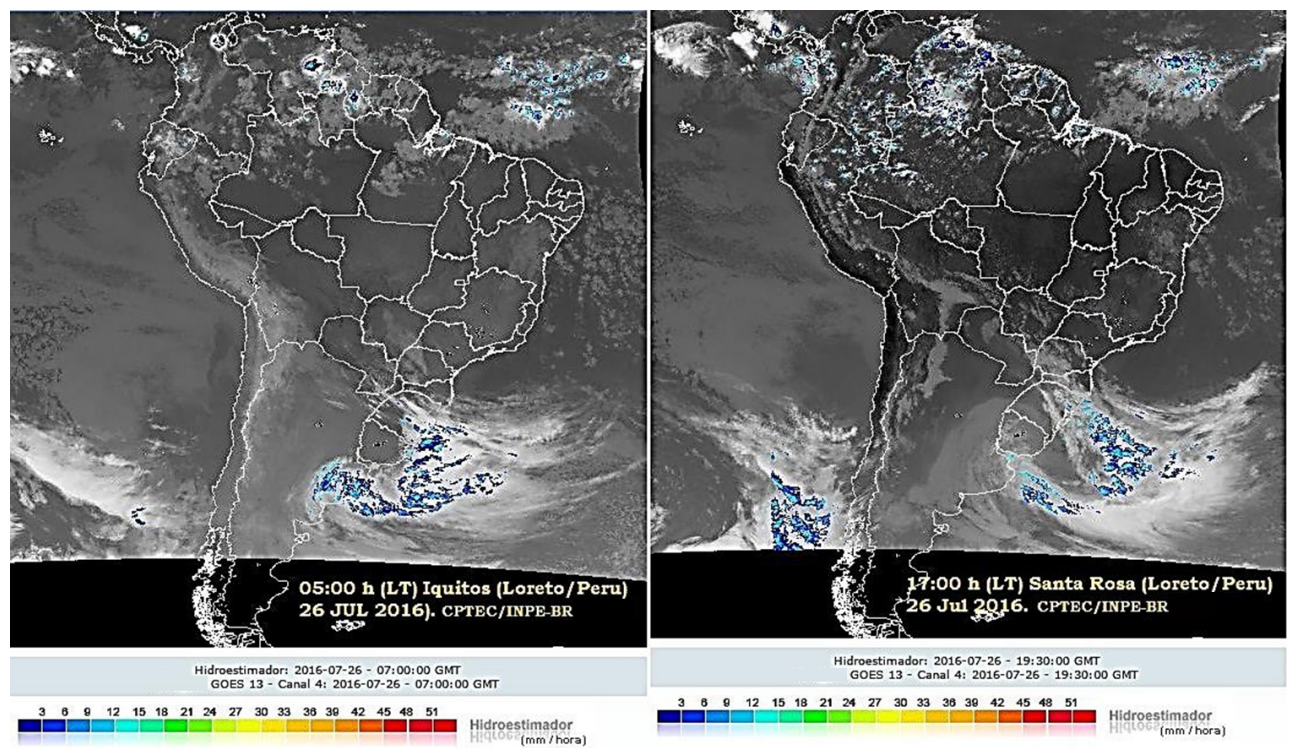

Figure 4 - Meteorological conditions on July 26, 2016, between 05:00 LT and 17:00 LT for South America. (Source: CPTEC/INPE, 2016).

Table 2 - Water levels at the hydrological monitoring stations during floods between 2013 and 2016 for the Amazon River (Solimões from Tabatinga to Manaus). Source: ANA/CPRM/SIPAM, 2016.

\begin{tabular}{|c|c|c|c|c|c|c|}
\hline \multirow{2}{*}{ STATION } & \multirow{2}{*}{ RIVER } & \multicolumn{2}{|c|}{$\begin{array}{c}\text { MAXIMUM WATER } \\
\text { LEVEL }\end{array}$} & \multirow{2}{*}{$\begin{array}{c}\text { RELATION WITH } \\
\text { MAXIMUM WATER }\end{array}$} & \multicolumn{2}{|c|}{$\begin{array}{c}\text { MOST RECENT } \\
\text { INFORMATION }\end{array}$} \\
& & YEAR & $\begin{array}{c}\text { WATER LEVEL } \\
\text { LEVEL }\end{array}$ & $\mathbf{( c m )}$ & DATE & $\begin{array}{c}\text { LEVEL } \\
\text { (cm) }\end{array}$ \\
\hline TABATINGA & SOLIMÕES & 1999 & 1382 & -648 & $11 / 29 / 2013$ & 734 \\
\hline ITAPEUÁ & SOLIMÕES & 2012 & 1765 & -823 & $11 / 27 / 2013$ & 942 \\
\hline MANACAPURU & SOLIMÕES & 2012 & 2068 & -937 & $11 / 27 / 2013$ & 1131 \\
\hline TABATINGA & SOLIMÕES & 1999 & 1382 & -352 & $01 / 23 / 2014$ & 1030 \\
\hline ITAPEUÁ & SOLIMÕES & 2012 & 1765 & -598 & $01 / 23 / 2014$ & 1167 \\
\hline MANACAPURU & SOLIMÕES & 2012 & 2068 & -690 & $01 / 23 / 2014$ & 1378 \\
\hline TABATINGA & SOLIMÕES & 1999 & 1382 & -299 & $01 / 22 / 2014$ & 1083 \\
\hline ITAPEUÁ & SOLIMÕES & 2012 & 1765 & -491 & $01 / 22 / 2015$ & 1274 \\
\hline MANACAPURU & SOLIMÕES & 2012 & 2068 & -712 & $01 / 15 / 2015$ & 1356 \\
\hline FONTE BOA & SOLIMÕES & 1999 & 2224 & -304 & $01 / 22 / 2015$ & 1920 \\
\hline CAREIRO & SOLIMÕES & 2012 & 1743 & -686 & $01 / 22 / 2015$ & 1057 \\
\hline TABATINGA & SOLIMÕES & 1999 & 1382 & -708 & $01 / 29 / 2016$ & 674 \\
\hline ITAPEUÁ & SOLIMÕES & 2015 & 1801 & -757 & $01 / 28 / 2016$ & 1044 \\
\hline MANACAPURU & SOLIMÕES & 2015 & 2078 & -928 & $01 / 28 / 2016$ & 1152 \\
\hline FONTE BOA & SOLIMÕES & 2015 & 2282 & -561 & $01 / 29 / 2016$ & 1721 \\
\hline CAREIRO & SOLIMÕES & 2012 & 1743 & -955 & $01 / 28 / 2016$ & 788 \\
\hline
\end{tabular}

effects associated with these forcings are also open to debate and probably will be for quite some time.

Figure 5 shows a graphical rhythmic analysis of weather types between Iquitos (Loreto-Peru), Tabatinga and São Paulo de Oliveira (State of Amazonas-Brazil) on July 26, 2016, between
05:00 LT and 18:00 LT in Peru, and July 27, 2016 (09:00 LT to 05:00 LT in Brazil), in which the climatic elements involved in this analysis of atmosphere dynamics are evident (CPTEC/INPE).

Figure 6 shows the time series of temperature that was taken at three positions (ambient temperature at the ship - 100 
Table 3 - Water levels at the hydrological monitoring stations during low-water between 2013 and 2016 for the Amazon River (Solimões from Tabatinga to Manaus). Source: ANA/CPRM/SIPAM, 2016.

\begin{tabular}{|c|c|c|c|c|c|c|}
\hline \multirow[t]{2}{*}{ STATION } & \multirow[t]{2}{*}{ RIVER } & \multicolumn{2}{|c|}{$\begin{array}{l}\text { MAXIMUM WATER } \\
\text { LEVEL }\end{array}$} & \multirow{2}{*}{$\begin{array}{l}\text { RELATION WITH } \\
\text { MAXIMUM WATER } \\
\text { LEVEL (cm) }\end{array}$} & \multicolumn{2}{|c|}{$\begin{array}{l}\text { MOST RECENT } \\
\text { INFORMATION }\end{array}$} \\
\hline & & YEAR & $\begin{array}{l}\text { WATER LEVEL } \\
(\mathrm{cm})\end{array}$ & & DATE & $\begin{array}{r}\text { LEVEL } \\
\text { (cm) }\end{array}$ \\
\hline TABATINGA & SOLIMÕES & 2010 & -86 & 820 & $11 / 29 / 2013$ & 734 \\
\hline ITAPEUÁ & SOLIMÕES & 2010 & 131 & 811 & $11 / 27 / 2013$ & 942 \\
\hline MANACAPURU & SOLIMÕES & 1997 & 495 & 636 & $11 / 27 / 2013$ & 1131 \\
\hline TABATINGA & SOLIMÕES & 2010 & -86 & 1116 & $01 / 23 / 2014$ & 1030 \\
\hline ITAPEUÁ & SOLIMÕES & 2010 & 131 & 1036 & $01 / 23 / 2014$ & 1167 \\
\hline MANACAPURU & SOLIMÕES & 1997 & 495 & 883 & $01 / 22 / 2014$ & 1378 \\
\hline TABATINGA & SOLIMÕES & 2010 & -86 & 1169 & $01 / 22 / 2015$ & 1083 \\
\hline ITAPEUÁ & SOLIMÕES & 2010 & 131 & 1143 & 01/22/2015 & 1274 \\
\hline MANACAPURU & SOLIMÕES & 1997 & 495 & 851 & $01 / 15 / 2015$ & 1356 \\
\hline FONTE BOA & SOLIMÕES & 2010 & 802 & 1118 & 01/22/2015 & 1920 \\
\hline CAREIRO & SOLIMÕES & 2010 & 125 & 932 & $01 / 22 / 2015$ & 1057 \\
\hline TABATINGA & SOLIMÕES & 2010 & -86 & 760 & $01 / 29 / 2016$ & 674 \\
\hline ITAPEUÁ & SOLIMÕES & 2010 & 131 & 913 & $01 / 28 / 2016$ & 1044 \\
\hline MANACAPURU & SOLIMÕES & 1997 & 495 & 657 & $01 / 28 / 2016$ & 1152 \\
\hline FONTE BOA & SOLIMÕES & 2010 & 802 & 919 & $01 / 29 / 2016$ & 1721 \\
\hline CAREIRO & SOLIMÕES & 2010 & 125 & 653 & $01 / 28 / 2016$ & 788 \\
\hline
\end{tabular}

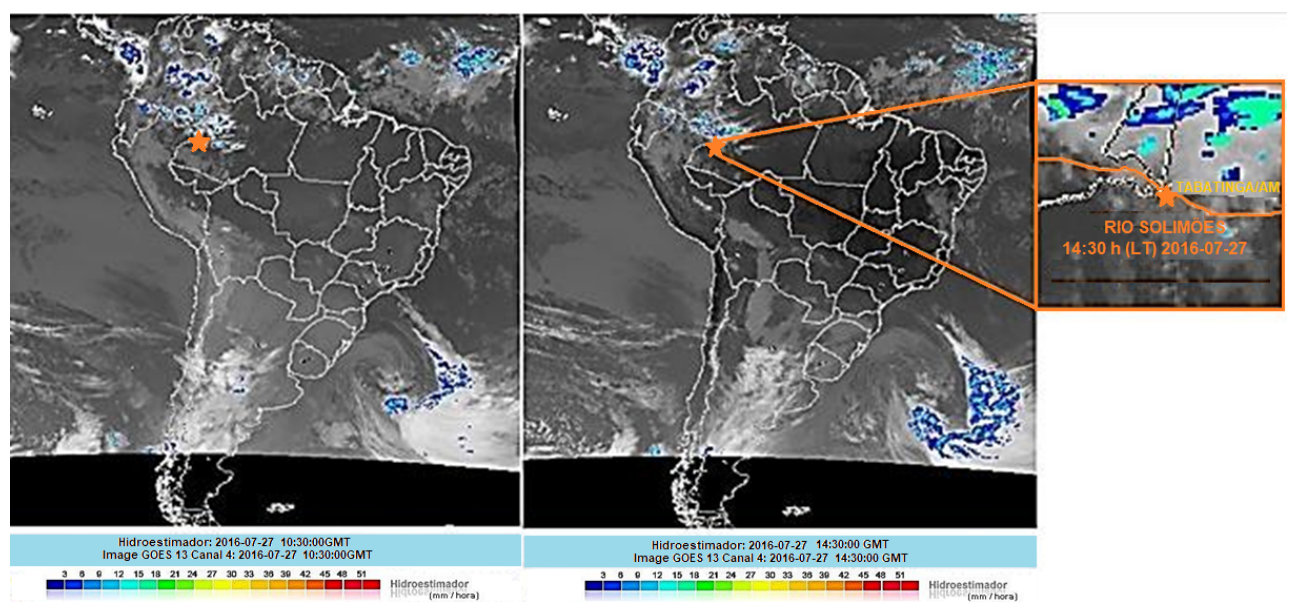

Figure 5 - Meteorological conditions on July 27, 2016, between 10:30 and 14:30 GMT, for South America. (Source: CPTEC/INPE, 2016).

$\mathrm{m}$ from the edge of the canal - middle of the canal) during the $1^{\text {st }}$ stage of the expedition (Iquitos/Peru - Manaus/Brazil), using the FLIR-E60 thermal imager. The image next to the time series shows SST in Real Time Global (RTG), High Resolution (HR) and was obtained by NOAA/NCEP/NWS/EMC (2017) by analyzing satellite images, ocean floats, sea ice cover, salinity, and conducting mathematical modeling in a second degree polynomial series (Branch analysis method), (ftp://tpprd.ncep.noaa.gov/pub/data/ $\mathrm{nccf} / \mathrm{com} / \mathrm{gfs} / \mathrm{prod}$ ), and indicates correlation with the results obtained by the Amazon River Expedition.

The observations from this study suggest regional warming of temperature gradients in the stretch between Iquitos-Peru to Manaus-Brazil) in July 2016 (dry season), with average ambient temperature at the ship (in the shade) of $30.41^{\circ} \mathrm{C}$, at the river's surface (100 $\mathrm{m}$ from the edge) of $27.34^{\circ} \mathrm{C}$, and at the middle of the canal of $24.73^{\circ} \mathrm{C}$ (Fig. 6). During the $2^{\text {nd }}$ stage of the 
Table 4 - Water sample analysis - Stage one of the Amazon River Expedition (Peru-Brazil), July 2016.

\begin{tabular}{|c|c|c|c|c|c|c|c|c|c|}
\hline \multirow{2}{*}{ Samples } & \multicolumn{2}{|c|}{ Geographic Coordenates } & \multirow{2}{*}{$\frac{\text { Water }}{}$} & \multirow{2}{*}{$\begin{array}{c}\text { Temp. } \\
{ }^{\circ} \mathrm{C}\end{array}$} & \multirow{2}{*}{$\begin{array}{c}\text { Conductivity } \\
(\mu \mathrm{S} / \mathrm{cm})\end{array}$} & \multirow{2}{*}{$\begin{array}{c}\text { Alkalinity } \\
\left(\mathrm{mgHCO}_{3} / \mathrm{L}\right)\end{array}$} & \multicolumn{2}{|c|}{ Dissolved Oxygen } & \multirow{2}{*}{$\frac{\text { Turbidity }}{\text { (NTU) }}$} \\
\hline & Longitude (S) & Latitude (W) & & & & & $\%$ & $\mathrm{mg} / \mathrm{L}$ & \\
\hline 1 & $S 03^{\circ} 43^{\prime} 37.6^{\prime \prime}$ & W $073^{\circ} 14^{\prime} 23.8^{\prime \prime}$ & 6.61 & 28.8 & 48.30 & 22.57 & 113.50 & 9.50 & 15.60 \\
\hline 2 & $\mathrm{~S} 03^{\circ} 48^{\prime} 18.8^{\prime \prime}$ & W $071^{\circ} 34^{\prime} 25.4^{\prime \prime}$ & 7.31 & 26.0 & 112.00 & 51.24 & 117.60 & 10.02 & 104.00 \\
\hline 3 & $S_{0} 04^{\circ} 00^{\prime} 59.6^{\prime \prime}$ & W $071^{\circ} 06^{\prime} 07.5^{\prime \prime}$ & 7.29 & 26.0 & 123.70 & 48.19 & 105.70 & 8.46 & 83.72 \\
\hline 4 & $S^{\prime} 03^{\circ} 55^{\prime} 40.8^{\prime \prime}$ & W $070^{\circ} 47^{\prime} 10.4^{\prime \prime}$ & 7.22 & 25.0 & 119.90 & 46.36 & 103.70 & 8.27 & 53.56 \\
\hline 5 & $\mathrm{~S}_{03^{\circ}} 53^{\prime} 49.0^{\prime \prime}$ & W $070^{\circ} 30^{\prime} 19.1^{\prime \prime}$ & 7.79 & 26.0 & 117.40 & 47.58 & 111.80 & 8.81 & 50.18 \\
\hline 6 & $S 04^{\circ} 06^{\prime} 39.7^{\prime \prime}$ & W $070^{\circ} 03^{\prime} 13.8^{\prime \prime}$ & 6.92 & 29.0 & 78.10 & 36.60 & 108.10 & 9.31 & 8.84 \\
\hline 7 & $\mathrm{~S}_{04^{\circ}} 13^{\prime} 04.7^{\prime \prime}$ & W $069^{\circ} 57^{\prime} 19.1^{\prime \prime}$ & 6.89 & 27.0 & 106.50 & 48.19 & 108.00 & 8.56 & 79.56 \\
\hline 8 & S $04^{\circ} 13^{\prime} 44.4^{\prime \prime}$ & W $069^{\circ} 56^{\prime} 41.0^{\prime \prime}$ & 7.20 & 27.0 & 103.70 & 44.53 & 109.20 & 9.44 & 75.40 \\
\hline 9 & 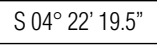 & W $070^{\circ} 01^{\prime} 34.3^{\prime \prime}$ & 7.15 & 26.0 & 104.30 & 47.58 & 110.20 & 8.36 & 73.06 \\
\hline 10 & S $04^{\circ} 18^{\prime} 31.2^{\prime \prime}$ & W $069^{\circ} 33^{\prime} 27.5^{\prime \prime}$ & 6.60 & 24.0 & 28.30 & 13.42 & 115.80 & 9.29 & 41.08 \\
\hline 11 & $\mathrm{~S}_{0} 03^{\circ} 27^{\prime} 42.2^{\prime \prime}$ & W $068^{\circ} 57^{\prime} 26.4^{\prime \prime}$ & 7.17 & 24.0 & 100.30 & 42.09 & 124.00 & 9.85 & 83.98 \\
\hline 12 & $S 03^{\circ} 21^{\prime} 14.5^{\prime \prime}$ & W $068^{\circ} 11^{\prime} 04.2^{\prime \prime}$ & 7.00 & 24.0 & 98.10 & 43.31 & 113.20 & 9.75 & 82.42 \\
\hline 13 & $\mathrm{~S} 03^{\circ} 06^{\prime} 29.1^{\prime \prime}$ & W $067^{\circ} 56^{\prime} 39.6^{\prime \prime}$ & 5.81 & 23.0 & 9.51 & 4.27 & 99.80 & 9.71 & 6.24 \\
\hline 14 & $\mathrm{~S}_{02^{\circ}} 51^{\prime} 47.0^{\prime \prime}$ & W $067^{\circ} 46^{\prime} 13.4^{\prime \prime}$ & 6.15 & 26.0 & 17.45 & 9.15 & 117.50 & 9.61 & 21.06 \\
\hline 15 & S $02^{\circ} 44^{\prime} 33.8^{\prime \prime}$ & W $066^{\circ} 46^{\prime} 19.5^{\prime \prime}$ & 6.16 & 25.0 & 17.92 & 9.76 & 109.00 & 8.99 & 10.92 \\
\hline 16 & S $02^{\circ} 29^{\prime} 40.6^{\prime \prime}$ & W $066^{\circ} 04^{\prime} 05.1^{\prime \prime}$ & 7.00 & 25.5 & 75.00 & 32.33 & 119.50 & 9.48 & 54.60 \\
\hline 17 & $\mathrm{~S}_{03^{\circ}} 16^{\prime} 32.1^{\prime \prime}$ & W $064^{\circ} 43^{\prime} 12.1^{\prime \prime}$ & 6.87 & 25.5 & 68.50 & 29.89 & 118.90 & 9.92 & 63.44 \\
\hline 18 & $\mathrm{~S}^{\prime} 03^{\circ} 47^{\prime} 18.3^{\prime \prime}$ & W $064^{\circ} 02^{\prime} 19.8^{\prime \prime}$ & 6.93 & 27.0 & 69.30 & 31.72 & 108.30 & 9.07 & 42.12 \\
\hline 19 & 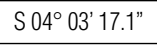 & W $063^{\circ} 04^{\prime} 54.0^{\prime \prime}$ & 6.89 & 26.0 & 64.20 & 30.50 & 110.00 & 9.42 & 44.20 \\
\hline 20 & $S 03^{\circ} 47^{\prime} 17.2^{\prime \prime}$ & W $061^{\circ} 37^{\prime} 05.8^{\prime \prime}$ & 6.76 & 25.0 & 54.40 & 25.01 & 100.70 & 8.34 & 29.38 \\
\hline 21 & $\mathrm{~S}_{0} 03^{\circ} 33^{\prime} 34.6^{\prime \prime}$ & W $060^{\circ} 53^{\prime} 16.0^{\prime \prime}$ & 6.75 & 24.5 & 50.70 & 23.79 & 103.80 & 7.79 & 44.46 \\
\hline 22 & 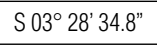 & W $060^{\circ} 45^{\prime} 22.9^{\prime \prime}$ & 6.76 & 26.0 & 48.10 & 22.57 & 119.10 & 9.00 & 20.80 \\
\hline 23 & $\mathrm{~S} 03^{\circ} 19^{\prime} 17.3^{\prime \prime}$ & W $060^{\circ} 37^{\prime} 00.6^{\prime \prime}$ & 6.81 & 23.0 & 48.50 & 22.57 & 129.70 & 10.45 & 29.38 \\
\hline 24 & $\mathrm{~S}_{03^{\circ}} 19^{\prime} 17.3^{\prime \prime}$ & W $060^{\circ} 37^{\prime} 00.6^{\prime \prime}$ & 6.77 & 27.0 & 48.60 & 22.57 & 108.50 & 9.11 & 24.44 \\
\hline 25 & $S 03^{\circ} 08^{\prime} 11.1^{\prime \prime}$ & W $059^{\circ} 53^{\prime} 59.1^{\prime \prime}$ & 5.53 & 28.0 & 9.00 & 3.66 & 114.80 & 9.61 & 3.64 \\
\hline
\end{tabular}

Table 5 - Water sample analysis - Stage two of the Amazon River Expedition (Peru-Brazil), December 2016.

\begin{tabular}{|c|c|c|c|c|c|c|c|c|c|}
\hline \multirow{2}{*}{ Samples } & \multicolumn{2}{|c|}{ Geographic Coordenates } & \multirow{2}{*}{$\begin{array}{c}\text { Water } \\
\mathrm{pH}\end{array}$} & \multirow{2}{*}{$\begin{array}{c}\text { Temp. } \\
{ }^{\circ} \mathrm{C}\end{array}$} & \multirow{2}{*}{$\begin{array}{c}\text { Conductivity } \\
(\mu \mathrm{S} / \mathrm{cm}) \\
\end{array}$} & \multirow{2}{*}{$\begin{array}{c}\text { Oxygen } \\
\mathrm{mg} / \mathrm{L} \\
\end{array}$} & \multirow{2}{*}{$\begin{array}{c}\text { Saturation of Oxygen } \\
\% \\
\end{array}$} & \multirow{2}{*}{$\begin{array}{c}\text { Alkalinity } \\
\left(\mathrm{mgHCO}_{3} / \mathrm{L}\right)\end{array}$} & \multirow{2}{*}{$\begin{array}{c}\text { Turbidity } \\
\text { (NTU) } \\
\end{array}$} \\
\hline & Longitude (N-S) & Latitude (W) & & & & & & & \\
\hline 1 & 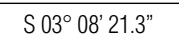 & W $060^{\circ} 01^{\prime} 35.1^{\prime \prime}$ & 5.14 & 27.6 & 7.92 & 5.76 & 77.00 & 2.44 & 3.90 \\
\hline 2 & ${\mathrm{~S} 03^{\circ} 08^{\prime} 54.3^{\prime \prime}}^{\prime}$ & W $058^{\circ} 26^{\prime} 54.1^{\prime \prime}$ & 6.56 & 27.0 & 53.30 & 5.35 & 76.60 & 17.08 & 35.36 \\
\hline 3 & $S 02^{\circ} 38^{\prime} 01.6^{\prime \prime}$ & W $056^{\circ} 45^{\prime} 21.7^{\prime \prime}$ & 6.70 & 27.0 & 51.30 & 5.66 & 69.30 & 16.47 & 44.46 \\
\hline 4 & 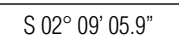 & W $056^{\circ} 05^{\prime} 43.1^{\prime \prime}$ & 6.54 & 27.0 & 51.20 & 5.63 & 70.50 & 15.25 & 37.44 \\
\hline 5 & S $01^{\circ} 55^{\prime} 22.2^{\prime \prime}$ & W $055^{\circ} 30^{\prime} 55.3^{\prime \prime}$ & 6.75 & 27.0 & 52.80 & 5.64 & 68.80 & 18.30 & 38.48 \\
\hline 6 & S 0 02 24'52.1" & W $054^{\circ} 44^{\prime} 13.8^{\prime \prime}$ & 6.16 & 27.0 & 13.80 & 5.68 & 74.90 & 7.32 & 4.68 \\
\hline 7 & ${\mathrm{~S} 02^{\circ} 25^{\prime} 00^{\prime \prime}}^{\prime}$ & W $054^{\circ} 43^{\prime} 22.2^{\prime \prime}$ & 6.07 & 27.0 & 13.92 & 6.36 & 82.50 & 6.10 & 2.60 \\
\hline 8 & 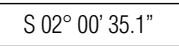 & W $054^{\circ} 04^{\prime} 10.0^{\prime \prime}$ & 6.54 & 27.0 & 45.70 & 5.29 & 67.20 & 16.47 & 57.46 \\
\hline 9 & 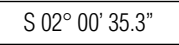 & W $054^{\circ} 04^{\prime} 11.8^{\prime \prime}$ & 6.41 & 26.6 & 50.00 & 4.98 & 64.05 & 17.69 & 41.34 \\
\hline 10 & S $01^{\circ} 31^{\prime} 58.7^{\prime \prime}$ & W $052^{\circ} 34^{\prime} 34.5^{\prime \prime}$ & 6.45 & 28.0 & 47.50 & 5.28 & 71.20 & 21.96 & 33.28 \\
\hline 11 & $S 00^{\circ} 03^{\prime} 27.4^{\prime \prime}$ & W $051^{\circ} 10^{\prime} 42.1^{\prime \prime}$ & 6.50 & 27.0 & 53.10 & 4.70 & 58.40 & 23.18 & 27.56 \\
\hline 12 & $\mathrm{~N} 00^{\circ} 01^{\prime} 37.4^{\prime \prime}$ & W $051^{\circ} 02^{\prime} 55.1^{\prime \prime}$ & 6.60 & 26.3 & 53.30 & 5.96 & 71.90 & 22.57 & 27.56 \\
\hline 13 & N 00 $02^{\prime} 00.2^{\prime \prime}$ & W $051^{\circ} 02^{\prime} 43.1^{\prime \prime}$ & 6.44 & 27.0 & 56.50 & 5.37 & 67.70 & 25.01 & 27.30 \\
\hline 14 & $S 00^{\circ} 31^{\prime} 20.0^{\prime \prime}$ & W $051^{\circ} 29^{\prime} 59.7^{\prime \prime}$ & 6.81 & 26.6 & 45.90 & 4.94 & 65.30 & 21.35 & 36.92 \\
\hline 15 & 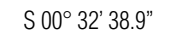 & W $051^{\circ} 31^{\prime} 47.7^{\prime \prime}$ & 6.84 & 27.0 & 46.40 & 4.00 & 67.30 & 21.96 & 36.48 \\
\hline
\end{tabular}



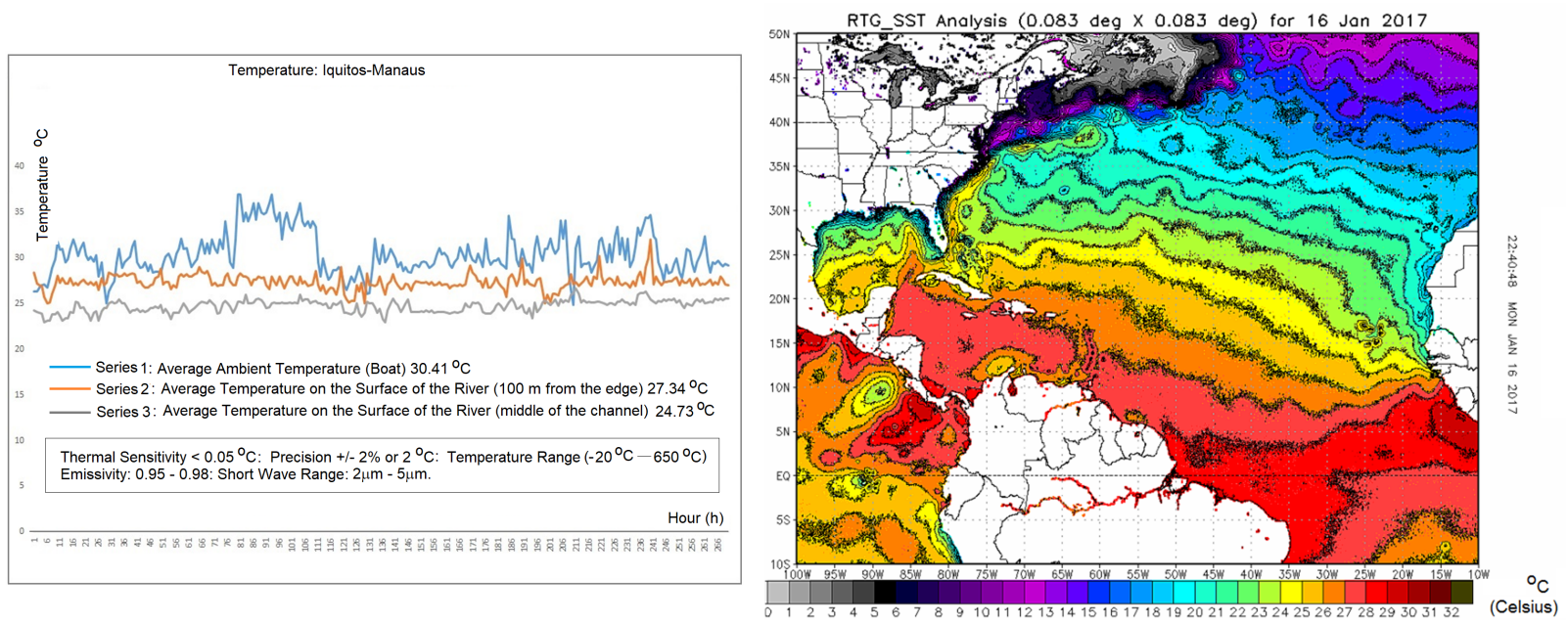

Figure 6 - Time series of temperature along the Amazon River during the first stage of the Expedition (Iquitos/Peru-Manaus/Brazil), and compared to data from the Marine Modeling and Analysis Branch Oper H.R. (Verification Ensembles) of NOAA/NWS/NCEP/EMC. Source: Amazon River Expedition and NOAA, 2016.
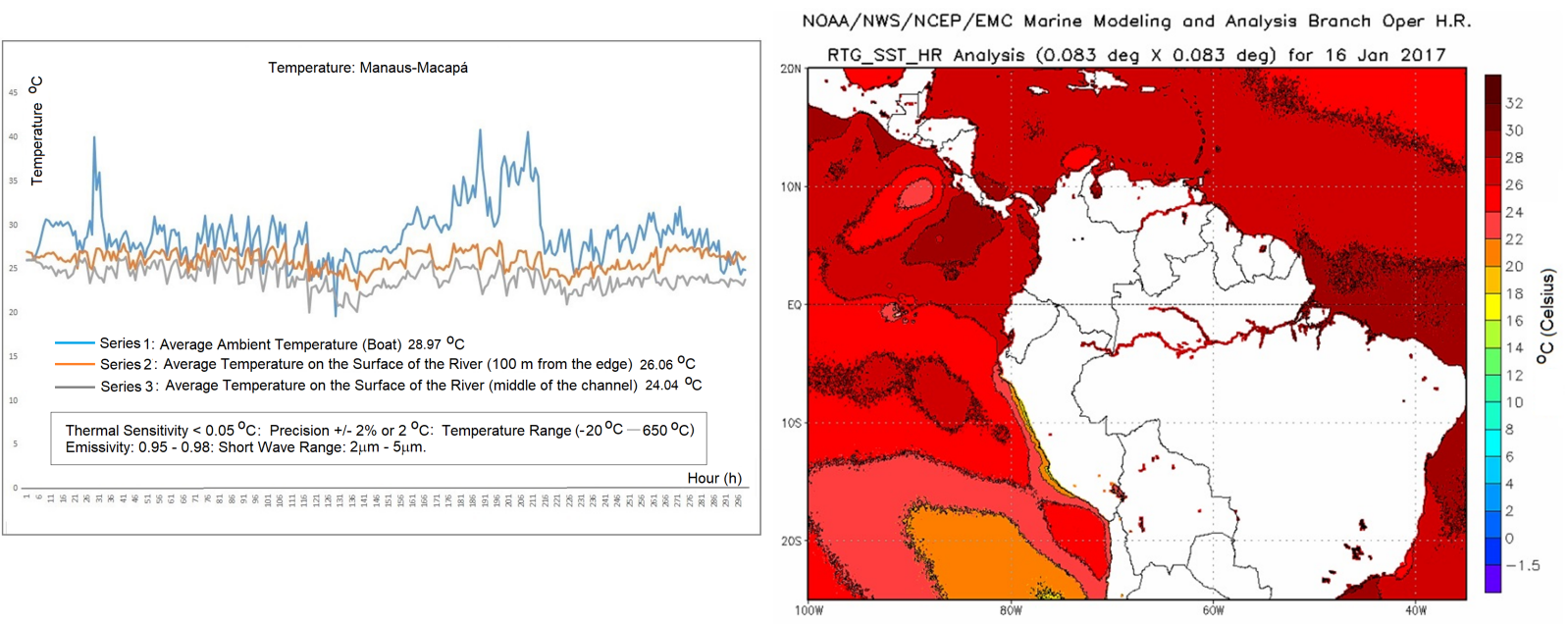

Figure 7 - Time series of temperature along the Amazon River during the second stage of the Expedition (Manaus/Brazil - Macapá/Brazil), and compared to data from the Marine Modeling and Analysis Branch Oper H.R. (Verification Ensembles) of NOAA/NWS/NCEP/EMC. Source: Amazon River Expedition and NOAA, 2016.

Expedition (Manaus-Brazil to Macapá-Brazil) in December 2016, the rainy season had already begun and average temperatures were slightly reduced, with average ambient temperature at the ship of $28.97^{\circ} \mathrm{C}$, at the river's surface ( $100 \mathrm{~m}$ from the edge) of $26.06^{\circ} \mathrm{C}$, and at the middle of the canal of $24.04^{\circ} \mathrm{C}$. The interval between the first and second stages was taken in order to be able to verify the effect of drought on the river due to the time necessary for water to flow across the large distance from lquitos-Peru to Macapá-Brazil (Fig. 7). The margin of error is shown in Figures 6 and 7 and in Table 1.

The time series of temperature was taken at three positions (ambient temperature at the ship - $100 \mathrm{~m}$ from the edge of the canal - middle of the canal) during the $2^{\text {nd }}$ stage of the Expedition (Manaus-Brazil to Macapá-Brazil) in December 2016 using the FLIR-E60 thermal imager. The image next to the time series shows SST in Real Time Global (RTG), High Resolution (HR) and was obtained by NOAA/NCEP/NWS/EMC (2017) and indicates correlation with the results obtained by the Amazon River Expedition (Fig. 7).

The analyses of the water samples from both stages of the expedition are listed in Tables 4 ( $1^{\text {st }}$ stage) and 5 ( $2^{\text {nd }}$ stage), and these data describe the "actual state" of the Amazon River in 2016 during the dry season in the Amazon. In Tabatinga at the entry of the Amazon River into Brazil, during the month of 
July 2016, the level of the Solimões River (the name given to the river from this point to Manaus, Brazil) was $5.54 \mathrm{~m}$ (at the end of the rainy season it was $11.62 \mathrm{~m}$ at this sampling point in May 2016), and the highest level recorded here was in May 1999 when the depth was $13.38 \mathrm{~m}$ with respect to sea level (ANA/CPRM/SIPAM, 2016). During this period of the expedition the El Niño climate phenomenon was already firmly established in the region since it had begun in 2014, lasted for all of 2015, and was still strong in 2016. The effects of this drought were clearly visible during the entire voyage along the river from Peru to the Atlantic, principally due to the marks left on trees in the lowland areas at the river's edge by the previous high-water season. However, the quality of the water from the Amazon River at the 39 georeferenced sample points (Tables 4 and 5) was satisfactory and within the standard for potable water for human consumption by communities adjacent to the river's edge from the western portion of the basin to the Atlantic, although basic sanitation services are a preoccupation for all the communities located at these 39 sampling points, including for Iquitos (Peru), Manaus, Santarém and Macapá (Brazil).

At the end of December 2016, the Tapajós River in Santarém, Pará, Brazil, located in the lower Amazon region, was more than $6 \mathrm{~m}$ below the base of the contention dike that serves as a waterfront walkway for urban dwellers along the Tapajós' edge in front of the city. A vertical line near the pier in front of the church of Nossa Senhora da Conceição approximately $5 \mathrm{~m}$ above the base of this dike represented the maximum extent of the previous high-water mark, and this mark extended for more than $60 \mathrm{~m}$ horizontally to near the municipal fish market. Rainfall is still sporadic during this period of the year in Santarém and almost always occurs early in the first hours of the morning before sunrise or at the end of the afternoon but is always brief in duration.

Nearing the mouth of the Amazon River, the weather was constantly cloudy with grey and dark, low nimbostratus (Ns) clouds at about 2,000 to 3,000 m, with a constant fine rain near Prainha (Pará/Brazil) and Almeirim (Pará/Brazil), (08:20 LT), and the air temperature and the dew point temperature at the level of the river's surface were very similar, indicating a condition of saturation. There was fog on the horizon, and this fog goes by the name of hot fog because the drops are well above the freezing temperature. It was most likely an advective fog in function of the horizontal dynamic of atmospheric migration that was in a situation that was more adequate for saturation, since, being nearer to the Atlantic 0cean (approximately $300 \mathrm{~km}$ ), the ocean breeze that penetrates the coast of Amapá at Macapá (Brazilian
Atlantic coast), in this period of the year has favorable conditions for the trade winds, including for the ITCZ, that can stimulate the development of climatic variation in this region of the Amazon River.

\section{RECOMMENDATION}

At the website https://sites.google.com/view/amazonriverexpedition there is more information about the "actual state" of the Amazon River in 2016, not only with respect to climatology, but also with respect to the life of people in the communities in this region.

\section{CONCLUSION}

The Amazon River, during the dry season of 2016, was influenced by a prolonged El Niño climatic tendency (2014, 2015 and 2016). The results show that there was a reduction in water levels along the entire sampling trip on the river, from the city of Iquitos in Peru to the Brazilian city of Macapá near the interface of Brazil and the Atlantic Ocean. The sea surface temperature stimulated the establishment of an increasing temperature gradient in the equatorial region along the river, up to its mouth at the Atlantic Ocean, where the river accompanied the same temperature regime as the ocean during this period. This gradient established the climatic phenomenon called the wet-dry dipole, combined with a tendency for regional warming during the El Niño event of 2016.

However, it is important to note that the ITCZ, which normally migrates to the south from its northern position during an El Niño, has not crossed the equator since 1998 (Hu \& Fedorov, 2018), and this for us is a strong indicator of the reduced quantity of rainfall over the Amazon. The improved determination of ENSO predictability, teleconnections, and impacts requires a better understanding of event-to-event differences in ENSO spatial patterns and evolution (Capotondi et al., 2015).

\section{ACKNOWLEDGEMENTS}

The authors are grateful to the Lutheran University Center of Manaus (Centro Universitário Luterano, Manaus CEULM/ULBRA) for the help with setting up this bi-national research trip, the Brazilian Navy in the Amazon (western and eastern regiments) for information that helped with navigation, the Foundation for the Support of Research of the State of Amazonas (Fundação de Amparo à Pesquisa do Estado do Amazonas - FAPEAM) that provided a scholarship student to conduct the water analyses, the Max Planck Chemistry Institute (Mainz-Germany) for support with the chemical analyses, and the 
Mauá group at INPA in Manaus/Brazil. Furthermore, the authors thank the Secretary of Education and Quality of Teaching of the State of Amazonas, that through the DEPPE, provided logistical support in sampling areas in the State of Amazonas, Brazil, and the Environmental Engineering sector of Honda of the Amazon, the engineers Feijão, Mirian, Mário, and Murakami for physical support with material used in the field, and also the Consul of Peru in Manaus, Dr. Javier Arteta Valencia for his orientation, and the Consul of Brazil Dr. Salvador R. Vecchio in Iquitos for providing access to sites in Peru. Additionally, the authors thank the Institute of Investigation of the Peruvian Amazon (IIAP) in Iquitos, Peru, specificaly the Director Dr. Luis Campo Baca and his team, for the logistical support and the dissemination and promotion of this research expedition, the Superintendency of the Federal Police -Tabatinga-Amazonas/Brazil, the Migration and Foreign Visitor Service of Peru (Manaus, Santa Rosa and Iquitos), and the collaborators Eliomar Oliveira, Maurício Benzecry, Abrahão Barros, Gilberto Carvalho, and Francisco Santana.

\section{REFERENCES}

ANA/CPRM/SIPAM. 2016. Hydrological Monitoring. National Water Agency. Geological Service of Brazil. Protection System of the Amazon. Report card. \# 18. Available on: <https://www.cprm.gov.br/sace/ boletins/Amazonas/20160513_19-20160513\%20-\%20191650.pdf>. Access on: September 2, 2017.

APHA. 1985. Standard Methods for the examination of water and wastewater. American Public Health Association.

APHA. 2003. Standard Methods for the examination of water and wastewater. American Public Health Association.

ASHOK K, BEHERA S, RAO S, WENG H \& YAMAGATA T. 2007. EI Niño Modoki and its possible teleconnection. Journal of Geophysical Research, 112: C11007. doi: 10.1029/2006JC003798.

CAPOTONDI A, WITTENBERG AT, NEWMAN M, DI LORENZO E, YU JY, BRACONNOT P, COLE J, DEWITTE B, GIESE B, GUILYARDI E, JIN FF, KARNAUSKAS K, KIRTMAN B, LEE T, SCHNEIDER N, XUE Y \& YEH SW. 2015. Understanding ENSO Diversity. Bulletin of the American Meteorological Society, 96(6): 921-938.

CCEE. 2017. Câmara de Comercialização de Energia Elétrica. Available on: <https:.//economia.uol.com.br/noticias/Reuters/2017/09/20>. Access on: September 10, 2017.

CPTEC. 2016. DSA - Satellite Division and Environmental Systems. Centro de Previsão de Tempo e Estudos Climáticos - CPTEC/INPE. Available on: <http://satelite.cptec.inpe.br/home/index.jsp>. Access on: July/December, 2016.
ERFANIAN A, WANG G \& FOMENKO L. 2017. Unprecedented drought over tropical South America in 2016: significantly under-predicted by tropical SST. Scientific Reports, 5811(2017). doi: 10.1038/s415998-017-05373-2.

GOLTERMAN HL, CLYMO RS \& OHNSTAD MAM. 1978. Methods for Physical and Chemical Analysis of Fresh Waters. Volume 8 of IBP Handbook. United Kingdom: Blackwell. Reporting year: 1978.

HU S \& FEDOROV AV. 2018. Cross-equatorial winds control El Niño diversity and change. Nature Climate Change, 8: 798-802. doi: 10.1038/ s41558-018-0248-0.

INESON S, BALMASEDA M, DAVEY M, DECREMER D, DUNSTONE N, GORDON M, REN H, SCAIFE A \& WEISHEIMER A. 2018. Predicting El Niño in 2014 and 2015. Scientific Reports, 8: 10733. doi: 10.1038/ s41598-018-29130-1.

JIMÉNEZ-MUÑOZ JC, MATTAR C, BARICHIVICH J, SANTAMARÍA-ARTIGAS A, TAKAHASHI K, MALHI Y, SOBRINO JA \& VAN DER SCHRIER G. 2016. Record-breaking warming and extreme drought in the Amazon rainforest during the course of El Niño 2015-2016. Scientific Reports, 6: 33130.

KAO HY \& YU JY. 2009. Contrasting Eastern-Pacific and Central-Pacific Types of ENSO. Journal of Climate, 22(3): 615-632.

KUG JS, JIN FF \& AN SI. 2009. Two Types of El Niño Events: Cold Tongue El Niño and Warm Pool El Niño. Journal of Climate, 22(6): 1499-1515.

LIMA NS, TÓTA J, BOLZAN MJA, FERREIRA AS \& PIETZSCH M. 2017. A brief observation of the formation of coherent structures and turbulence over a rain forest area in Central Amazonia: the Atto-Claire/IOP-1/2012 experiment. Brazilian Journal of Geophysics, 35(3): 187-199.

MACKERETH FJH, HERON JT, TALLING JF. 1978. Water analysis: some revised methods for limnologists. Ambleside (UK): Freshwater Biological Association.

MARENGO JA, TOMASELLA J \& UVO CR. 1998. Trends in streamflow and rainfall in tropical South America: Amazonia, eastern Brazil, and northwestern Peru. Journal of Geophysical Research: Atmospheres, 103(D2): 1775-1783.

MCPHADEN MJ, LEE T \& MCCLURG D. 2011. El Niño and its relationship to changing background conditions in the tropical Pacific Ocean. Geophysical Research Letters, 38(15): L15709.

MOHTADI M, PRANGE M, SCHEFUSS E \& JENNERJAHN TC. 2017. Late Holocene slowdown of the Indian Ocean Walker circulation. Nature Communications, 8: 1015.

NOAA/NCEP/NWS/EMC. 2017. Available on: <ttp://ttpprd.ncep. noaa.gov/pub/data/nccf/com/gfs/prod $>$. Access on: July/December, 2016/July, 2017. 
PALISSA A. 1972. Mitteilungen aus dem Museum für Naturkunde in Berlin. Zoologisches Museum und Institut für Spezielle Zoologie (Berlin), 48(2): 449-450

POVEDA G \& MESA OJ. 1997. Feedbacks between Hydrological Processes in Tropical South America and Large-Scale Ocean-Atmospheric Phenomena. Journal of Climate, 10(10):
2690-2702.

VALDERRAMA JC. 1981. The simultaneous analysis of total nitrogen and total phosphorus in natural waters. Marine Chemistry, 10(2): 109-122.

ZHU J, KUMAR A, HUANG B, BALMASEDA MA, HU ZZ, MARX L \& KINTER III JL. 2016. The role of off-equatorial surface temperature anomalies in the 2014 El Niño prediction. Scientific Reports, 6: 19677.

Recebido em 1 junho, 2018 / Aceito em 18 dezembro, 2018

Received on June 1, 2018 / accepted on December 18, 2018. 